\title{
Acetylenic alcohols as inhibitors of iron acid corrosion. Improvement of the inhibition efficiency of a class of substances based on their action mechanism
}

\author{
A. Frignani,* C. Monticelli, F. Zucchi and G. Trabanelli \\ Corrosion Study Centre "A. Daccò", University of Ferrara, \\ v.Saragat 1,44122 Ferrara(I).E-mail: a.frignani@unife.it
}

\begin{abstract}
This paper shows the results obtained in "A. Daccò" Corrosion Study Centre on the inhibition of iron acid corrosion by acetylenic alcohols. The improvement in the protective performances of this class of substances was obtained through base molecule modifications related to their action mechanism (i.e., initial adsorption onto the metal surface and successive polymeric layer formation). Therefore, in an attempt to favour molecular adsorption, some 3-methyl-1-butyne derivatives were modified by substituting the acetylenic hydrogen atom with halogen atoms $(\mathrm{Cl}, \mathrm{Br}$ or I), while alkyn-3-ols were modified by increasing their alkyl chain length to determine the subsequent polymeric layer improvement. The presence of halo-atoms of increasing polarizability favoured the inhibiting action of 3-methyl-1-butyne derivatives to the anodic reaction, while the lengthening of the alkyl chain in alkyn-3-ols promoted a marked increase in the inhibiting effects due to the formation of a thick layer. In this latter class of substances the iodine atom significantly increased the persistence of the inhibiting action.
\end{abstract}

Key words: acetylenic alcohols, acid, corrosion, inhibition, iron.

Received: February 25, 2014.

doi: 10.17675/2305-6894-2014-3-2-105-119

\section{Introduction}

Acetylenic derivatives (general formula $\mathrm{R}-\mathrm{C} \equiv \mathrm{C}-\mathrm{H}$ ) can be used to mitigate the corrosive attack suffered by iron alloys in hot acid environments [1-5], where they are usually more effective in hydrochloric than in sulphuric acid solutions [5]. The efficiency of these substances is related to the formation of an insoluble, hydrophobic, thick polymeric film, which lacks the original $\mathrm{C} \equiv \mathrm{C}$ triple bond [6-8]. The mechanism of film formation, studied in detail in the case of ethynylcyclohexanol [9], 1-octyn-3-ol [10-12], 3-phenyl-2-propyn1-ol [13], propargyl alcohol [14-16] generally involves the following consecutive steps: (i) inhibitor chemisorption onto the metal surface through $\pi$ electrons of the triple bond, (ii) triple bond hydrogenation by atomic hydrogen evolving during the cathodic process, (iii) dehydration (of the alcoholic function), with consequent reactive diene formation and, finally, (iv) polymerisation, reticulation. Detailed studies of chemisorption of alkynols using electrochemical and ellipsometric techniques [17-20] have established that the octynol molecule lies flat at low additive concentrations and short immersion times, or 
perpendicular at high concentrations and long contact times. This reorientation produced a high coverage, multilayered film and, consequently, a noticeable protective action.

The inhibitive performances of acetylenic compounds can be improved by proper changes in the base molecule, such as the presence of electron-withdrawing groups in the $\alpha$ position to the triple bond [7], particularly the hydroxyl group [21], the increase in the molecular weight [7], or a long aliphatic chain [7].

The aim of the present research was to study the influence of the substitution of the acetylenic hydrogen atom with halogens of increasing polarizability in 3-methyl-1-butyne (3M1B) derivatives (given the conflicting results in halogen-substituted acetylenic alcohols $[22,2,7])$, as well as that of the aliphatic chain length increase in a series of alkyn-3-ols. The former molecules were expected to bring about an improved inhibitor chemisorption, whereas an increased film thickness (or hydrophobicity) was foreseen for the latter ones. All these acetylenic compounds, characterized by the hydroxyl group adjacent to the triple bond, are potentially effective inhibitors for Armco iron acid corrosion [5].

To better discriminate their effects, the tests were carried out in deaerated diluted acid solutions $\left(1 \mathrm{M} \mathrm{HCl}\right.$ or $\left.0.5 \mathrm{M} \mathrm{H}_{2} \mathrm{SO}_{4}\right)$, chiefly at $70^{\circ} \mathrm{C}$, in the presence of $10^{-3} \mathrm{M}$ additive concentration. The inhibiting effects of the various acetylenic compounds were studied by an analytical technique (spectro-photometric analysis of dissolved iron by $o$-phenanthroline method) and by electrochemical methods (potentiodynamic polarization curves and impedance spectra) [23-25].

\section{Experimental}

Armco iron cylindrical electrodes (approx. measures: $\varnothing 1 \mathrm{~cm}, h 1 \mathrm{~cm}$ ), with a central threaded hole, mechanically obtained from a bar, were heat treated at $700^{\circ} \mathrm{C} \times 14 \mathrm{~h}$ in argon atmosphere. Before testing, their surfaces were emery paper treated (from 150 to 600 grit) and afterwards carefully degreased with acetone in an ultrasonic bath. Properly mounted, these specimens exposed only the lateral surface $\left(\sim 3 \mathrm{~cm}^{2}\right)$ to the aggressive solutions.

The aggressive environments were $\left(\mathrm{N}_{2}\right.$ purged) $0.5 \mathrm{M} \mathrm{H}_{2} \mathrm{SO}_{4}$ and $1 \mathrm{M} \mathrm{HCl}$ solutions, obtained by diluting Carlo Erba RPE concentrated solutions; the adopted temperatures were $25^{\circ} \mathrm{C}$ only for the former solution, and $70^{\circ} \mathrm{C}$ for both solutions. The inhibitor concentration was $10^{-3} \mathrm{M}$.

Some weight-loss measurements were carried out on Aq44 plain steel coupons (chemical composition: $0.16 \% \mathrm{C}, 0.89 \% \mathrm{Mn}, 0.17 \% \mathrm{Si}, 0.027 \% \mathrm{~S}, 0.024 \% \mathrm{P}$ ) in a solution simulating a cleaning process $\left(5 \% \mathrm{HCl}, 70^{\circ} \mathrm{C}\right.$, no $\mathrm{N}_{2}$ purging, $6 \mathrm{~h}$ testing, $0.2 \%$ additive amount).

The tested acetylenic compounds were:

a) 3-methyl-1-butyne (3M1B) derivatives (proprietary products) $\mathrm{CH}_{3} \mathrm{CY}\left(\mathrm{CH}_{3}\right) \mathrm{C} \equiv \mathrm{C}-\mathrm{X}$, where $\mathrm{Y}$ can be the $-\mathrm{OH}$ group (3-hydroxy-3M1B) and $\mathrm{X}=\mathrm{H}(1-\mathrm{H}), \mathrm{Cl}(1-\mathrm{Cl}), \mathrm{Br}(1-\mathrm{Br})$ and $\mathrm{I}(1-\mathrm{I})$, or the $-\mathrm{O}-\left(\mathrm{CH}_{2}\right)_{2} \mathrm{OH}$ group (3-ethoxy- $\omega$-hydroxy-3M1B) and $\mathrm{X}=\mathrm{H}(2-\mathrm{H}), \mathrm{Cl}$ $(2-\mathrm{Cl}), \mathrm{Br}(2-\mathrm{Br})$ and I (2-I); 
b) alkyn-3-ol derivatives (Lancaster products), $R \mathrm{CH}(\mathrm{OH}) \mathrm{C} \equiv \mathrm{C}-\mathrm{H}$ : 1-butyn-3-ol $(R=$ $\mathrm{CH}_{3}$, BUT), 1-hexyn-3-ol $\left(R=\mathrm{C}_{3} \mathrm{H}_{7}\right.$, HEX), 1-octyn-3-ol $\left(R=\mathrm{C}_{5} \mathrm{H}_{11}\right.$, OCT $)$ and their iododerivatives (i.e., BUT-I, HEX-I, OCT-I), prepared in the lab of the Organic Chemistry group of the Chemistry Dept. of the University of Ferrara, by low temperature reacting of the alkynols with iodine in a basic methanolic solution [26]. The synthesized substances were purified by flash chromatography and their purity was checked by thin layer chromatography, NMR and IR spectroscopy.

As usual, the proof cell was a $500 \mathrm{~mL}$ double-walled, thermostatted Pyrex glass cell, containing the working electrode (Armco iron electrode), the capillary for the reference electrode (SCE electrode) and two auxiliary Pt wire counter-electrodes, separated from the bulk solution by a sintered glass frit. The cell was equipped with a magnetic stirrer. All experiments were conducted under $\mathrm{N}_{2}$ bubbling. In this cell also the analysis of dissolved iron (spectrophotometric technique, $o$-phenanthroline method) was performed, by taking out aliquots $(1 \mathrm{~mL})$ of solutions at increasing testing times. EIS spectra were obtained (Solartron FRA 1250, EI 1286) at the free corrosion potentials at various testing times, by applying a $5 \mathrm{mV}$ rms sinusoidal perturbation, in the frequency interval $65 \mathrm{kHz}-10 \mathrm{mHz}$, five frequencies per decade, $10 \mathrm{~s}$ integration time. The potentiodynamic $(1 \mathrm{mV} / \mathrm{s})$ polarisation curves were recorded at various immersion times, on independent Armco iron specimens, with an AMEL Metalloscan .

Percent inhibiting efficiency (\%I.E.) values, obtained from dissolved iron analysis, were given by:

$$
\text { \%I.E. } \left.=\left[\left(v_{0}-v_{(\mathrm{INHIB})}\right) / \mathrm{v}_{0}\right) \times 100\right],
$$

where $v_{0}$ and $v_{\text {(INHIB) }}$ represented the constant iron dissolution rates in the uninhibited and inhibited solutions, respectively, determined in 6-24 h time interval in the sulphuric acid solutions, and $1-6 \mathrm{~h}$ time interval in the hydrochloric acid solutions.

In the case of the polarization curves, percent inhibiting efficiency values were given by:

$$
\left.\% \text { I.E. }=\left[\left(i_{\mathrm{CORR}(0)}-i_{\mathrm{CORR}(\mathrm{INHIB})}\right) / i_{\mathrm{CORR}(0)}\right) \times 100\right],
$$

where $i_{\mathrm{CORR}(0)}$ and $i_{\mathrm{CORR}(\mathrm{INHIB})}$ were the iron corrosion current densities obtained in the uninhibited and inhibited solutions, respectively, by cathodic Tafel line extrapolation to the corrosion potentials, when a steady-state condition was reached.

\section{Results}

\section{1) Analytical determination of dissolved iron}

In uninhibited sulphuric acid solution, at $25^{\circ} \mathrm{C}$, in the $1-24 \mathrm{~h}$ time interval, Armco iron dissolved at $0.265 \mathrm{mg} / \mathrm{cm}^{2} \cdot \mathrm{h}$ constant dissolution rate (Fig. 1, left), which increased to $5.3 \mathrm{mg} / \mathrm{cm}^{2} \cdot \mathrm{h}$ when the temperature was raised to $70^{\circ} \mathrm{C}$. In these solutions the acetylenic compounds developed their full protective action after a certain time interval, which was shorter at the higher temperature. For instance, at $25^{\circ} \mathrm{C}$, in the first $6 \mathrm{~h}$ immersion, the presence of $1-\mathrm{H}$ base molecule exerted a negligible influence on the iron dissolution 
(Fig. 1, left); successively this compound developed a limited inhibiting action $(\%$ E.I. $=$ 47). Its chloro and bromo derivatives also produced their effects after about the same time, while 1-I was quicker and more efficient in developing its action. The improvement in the protective effects followed the sequence: $1-\mathrm{H}<1-\mathrm{Cl}<1-\mathrm{Br}<1-\mathrm{I}$, however, \%I.E. values were not particularly interesting, reaching about 80 (Table 1 ). At $70^{\circ} \mathrm{C}$ the decrease in the dissolution rate took place after shorter immersion times than at $25^{\circ} \mathrm{C}$ : and, in the case of $1-\mathrm{H}, 1-\mathrm{Cl}, 1-\mathrm{Br}$, after around $2-3$ hours. With the $1-\mathrm{H}$ series, it was possible to ascertain that these inhibiting effects were greater than those at $25^{\circ} \mathrm{C}$, chiefly in the case of the iodocompound. For both the $1-\mathrm{H}$ and $2-\mathrm{H}$ series of compounds, the previously described inhibition efficiency trend was maintained, that is, the efficiency increased by substituting the acetylenic hydrogen atom with more and more polarizable halogen atoms. Therefore, both iodo-derivatives (chiefly 2-I) were particularly efficient, since they markedly decreased the Armco iron dissolution rate almost from the beginning of the experiment, attaining \%I.E. values over 95 (Table 1).
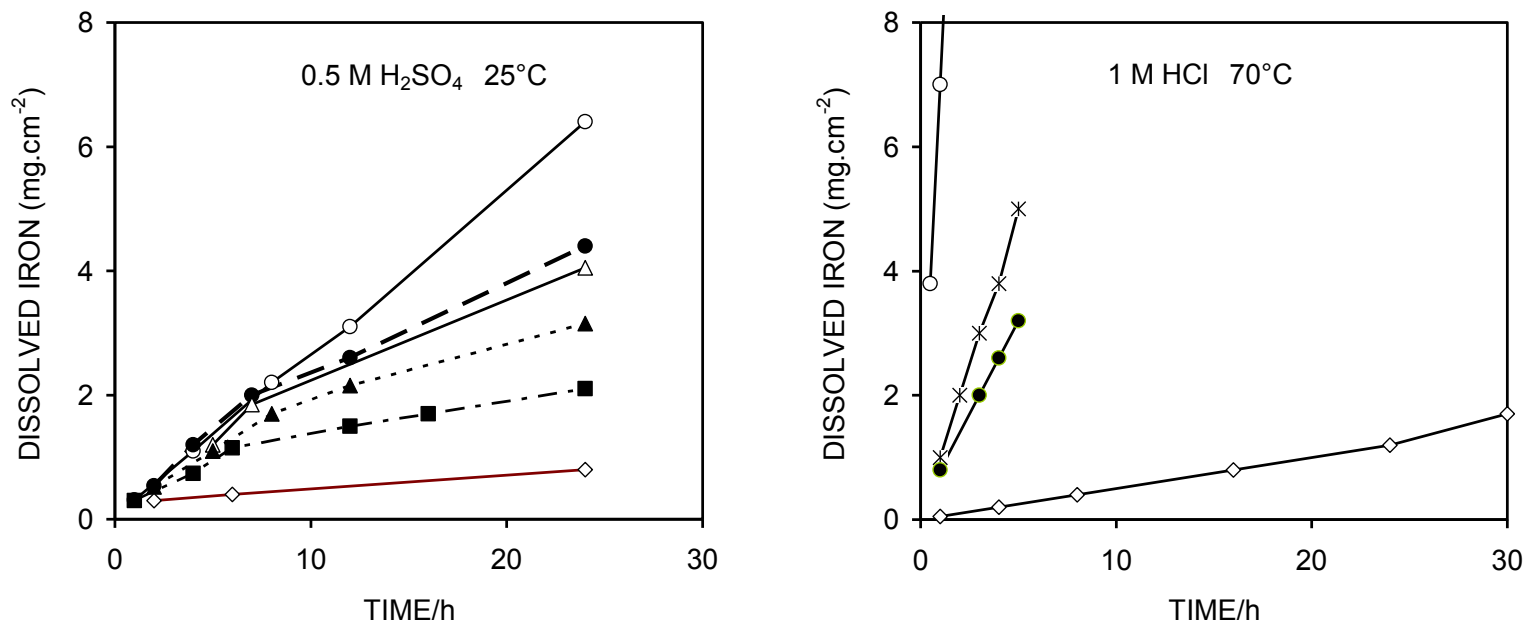

Figures 1. Examples of dissolved iron as a function of time in $0.5 \mathrm{M} \mathrm{H}_{2} \mathrm{SO}_{4}$ at $25^{\circ} \mathrm{C}$ (left) or in $1 \mathrm{M} \mathrm{HCl}$ at $70^{\circ} \mathrm{C}$ (right). Blank, open circles; 1-H, full circles; $2-\mathrm{H}$, stars; 1-Cl, open triangles; 1-Br, ful1 triangles; 1-I, full squares; OCT, open diamonds.

In the first 6 hour immersion in the hydrochloric acid solution $\left(70^{\circ} \mathrm{C}\right)$, the Armco iron dissolution rate was $6.85 \mathrm{mg} / \mathrm{cm}^{2} \cdot \mathrm{h}$ (Fig. 1, right). All compounds of the $1-\mathrm{H}$ and $2-\mathrm{H}$ series were also effective in this acid solution, and an elevated decrease in dissolved iron was revealed after only $1 \mathrm{~h}$ immersion. The substitution of the acetylenic hydrogen atom with halogen atoms once more improved the performances of the base molecules (Table 1) and, in comparison to the sulphuric solution, the inhibiting efficiency of both series of additives was improved (with the exception of the iodo-derivatives).

The presence of a long aliphatic chain (i.e., OCT) caused a marked improvement in the protective effects, which lasted for over $24 \mathrm{~h}$. For instance, in the sulphuric solution, at $25^{\circ} \mathrm{C}$, OCT developed an elevated and rapid inhibiting action (\%I.E. 87.5), which lasted for longer than $48 \mathrm{~h}$, in comparison to 80 of 1-I; in the hydrochloric acid solution, at $70^{\circ} \mathrm{C}$, 
its \%I.E. increased to over 99 in comparison to the maximum attained inhibition efficiency (around 90) of the lower homologues $(1-\mathrm{H}$ and $2-\mathrm{H})$. The introduction of the iodine atom in the OCT molecule (OCT-I) produced very positive results, which were greater in $0.5 \mathrm{M}$ $\mathrm{H}_{2} \mathrm{SO}_{4}$ than in $1 \mathrm{M} \mathrm{HCl}$, where the efficiency of OCT was higher

Table 1. Influence of the substitution of the acetylenic hydrogen atom with halo-atoms on the inhibiting efficiencies of some series of derivatives. Additive concentration: $10^{-3} \mathrm{M}$.

\begin{tabular}{ccccc}
\hline \multirow{2}{*}{ ADDITIVE } & & \multicolumn{2}{c}{$\mathbf{0 . 5} \mathbf{M ~ H} \mathbf{2}_{2} \mathbf{S O}_{\mathbf{4}}$} & $\mathbf{1} \mathbf{~ M ~ H C l}$ \\
\cline { 3 - 5 } & & $\mathbf{2 5}^{\circ} \mathbf{C}$ & $\mathbf{7 0}^{\circ} \mathbf{C}$ & $\mathbf{7 0}^{\circ} \mathbf{C}$ \\
\hline & $1-\mathrm{H}$ & 47 & 35 & 90.2 \\
3-hydroxy-3M1B & $1-\mathrm{Cl}$ & 51 & 52 & 92 \\
$\left(\mathrm{CH}_{3}\right)_{2} \mathrm{C}(\mathrm{OH}) \mathrm{C} \equiv \mathrm{C}-\mathrm{X}$ & $1-\mathrm{Br}$ & 66 & 72.6 & - \\
& $1-\mathrm{I}$ & 80 & 98.1 & 92.6 \\
\hline & $2-\mathrm{H}$ & - & 29.5 & 86.6 \\
3 3-hydroxy-ethoxy-3M1B & $2-\mathrm{Cl}$ & - & 52.7 & 91.2 \\
$\left(\mathrm{CH}_{3}\right)_{2} \mathrm{C}\left(\mathrm{OCH} \mathrm{H}_{2} \mathrm{CH} \mathrm{H}_{2} \mathrm{OH}\right) \mathrm{C} \equiv \mathrm{C}-\mathrm{X}$ & $2-\mathrm{Br}$ & - & 81.1 & 94 \\
& $2-\mathrm{I}$ & - & 99.2 & 95.6 \\
\hline 1-octyn-3-ol & OCT & 87.5 & 92.8 & 99.4 \\
$\mathrm{CH}_{3}\left(\mathrm{CH}_{2}\right)_{4} \mathrm{CH}(\mathrm{OH}) \mathrm{C} \equiv \mathrm{C}-\mathrm{X}$ & OCT-I & - & 99.95 & 99.6 \\
\hline
\end{tabular}

On the contrary, the lengthening of the aliphatic tail in the lateral position (i.e., the introduction of the ethoxy- $\omega$-hydroxy group) produced uninteresting results; in fact, in the hydrochloric solution, in the initial $1-8 \mathrm{~h}$ time interval, the lower homologues (i.e., 1- $\mathrm{H}, 2-$ $\mathrm{H})$ presented a similar reduced value of dissolved iron, attaining \%I.E. only around 90 (Fig. 1, right). For longer testing intervals, these values decreased. However, with the iododerivatives (1-I and 2-I), the dissolution rates were low and almost constant during the whole time interval, $24 \mathrm{~h}$.

Finally, the protective action of the 1-H and 2-H series of compounds was confirmed when they were tested in an acid cleaning process on a common carbon steel (Aq44) (Table 2: aerated $5 \% \mathrm{HCl}$ at $70^{\circ} \mathrm{C}, 0.2 \%$ additive amount, $6 \mathrm{~h}$ testing). The $\%$ I.E. values obtained were higher than those determined in deaerated $1 \mathrm{M} \mathrm{HCl}$ at the same temperature on pure iron (Table 1).

\section{2) Polarization curves}

In the sulphuric solution at low temperature the inhibiting action on the iron acid corrosion process exerted by the $1-\mathrm{H}$ series derivatives was mainly directed to the anodic dissolution reaction (Fig. 2, left). The presence of an easily polarizable halo-atom produced a remarkable effect; in fact, while 1-H scarcely hindered iron dissolution, the iodo-derivative 
diminished the anodic polarization currents by more than one order of magnitude, with a net positive shift of the corrosion potential. At $70^{\circ} \mathrm{C}$ these effects were improved (Fig. 2, right), and with 1-I a marked increase in the anodic Tafel slope took place, attesting the formation of a very protective layer [27-29] up to around $-0.4 \mathrm{~V}_{\mathrm{SCE}}$; in fact, successively, the anodic currents rapidly increased most likely due to the subsequent inhibitor desorption or protective film destruction. The 2-H series of compounds produced analogous effects: the anodic reaction was slightly inhibited by $\mathrm{H}, \mathrm{C}, \mathrm{Br}$ derivatives, but more efficiently by the iodo-compound. While at low temperature these compounds scarcely retarded the cathodic hydrogen evolution reaction (Fig. 2, left), by increasing the temperature the related inhibiting action improved: in comparison to the blank test, at $70^{\circ} \mathrm{C}$, the bromoderivative reduced the polarization currents by around one order of magnitude, while 1-I by about two orders of magnitude (Fig. 2, right), indicating the formation of a more compact and efficient film than at $25^{\circ} \mathrm{C}$.

Table 2. $-\%$ I.E. of the various compounds ( $0.2 \%$ additive concentration) towards Aq44 carbon steel corrosion in $5 \% \mathrm{HCl}$ at $70^{\circ} \mathrm{C}, 6 \mathrm{~h}$ immersion.

\begin{tabular}{ccc}
\hline ADDITIVE & & \%I.E. \\
\hline & $1-\mathrm{H}$ & - \\
$3-\mathrm{Hydroxy}-3 \mathrm{M} 1 \mathrm{~B}$ & $1-\mathrm{Cl}$ & 96.9 \\
$\left(\mathrm{CH}_{3}\right)_{2} \mathrm{C}(\mathrm{OH}) \mathrm{C} \equiv \mathrm{C}-\mathrm{X}$ & $1-\mathrm{Br}$ & 98.7 \\
& $1-\mathrm{I}$ & 99.0 \\
\hline & $2-\mathrm{H}$ & 96.0 \\
$3-\mathrm{Hydroxy}_{-}$ethoxy-3M1B & $2-\mathrm{Cl}$ & 97.4 \\
$\left(\mathrm{CH}_{3}\right)_{2} \mathrm{C}\left(\mathrm{OCH}_{2} \mathrm{CH}_{2} \mathrm{OH}\right) \mathrm{C} \equiv \mathrm{C}-\mathrm{X}$ & $2-\mathrm{Br}$ & 98.1 \\
& $2-\mathrm{I}$ & 99.6 \\
\hline
\end{tabular}

With OCT, in the sulphuric solution at $25^{\circ} \mathrm{C}$, the cathodic polarization currents were decreased by around two orders of magnitude, while the corresponding Tafel slope increased to over $300 \mathrm{mV} / \mathrm{dec}$ (Fig. 2, left), i.e., underlining that the reaction became diffusion-limited.

In the hydrochloric acid solution $\left(70^{\circ} \mathrm{C}\right)$, the cathodic reaction was significantly inhibited by all the additives, with a reduction in the polarization currents by around one order of magnitude and with negligible differences among them (Fig. 3). The anodic reaction was also inhibited, with the usual differences: $\mathrm{H}<\mathrm{Cl}<\mathrm{Br}<\mathrm{I}$.

In general, the presence of these halo-derivatives hardly affected the cathodic Tafel slopes, whose values remained close to that of the blank ( $b c$ around $120 \mathrm{mV} / \mathrm{dec}$ ); the anodic Tafel slope, (ba around $60 \mathrm{mV} / \mathrm{dec}$ in the uninhibited solutions) was markedly affected only by the iodo-compounds in the sulphuric solution at high temperature ( $b$ a around or over $120 \mathrm{mV} / \mathrm{dec}$ ). 

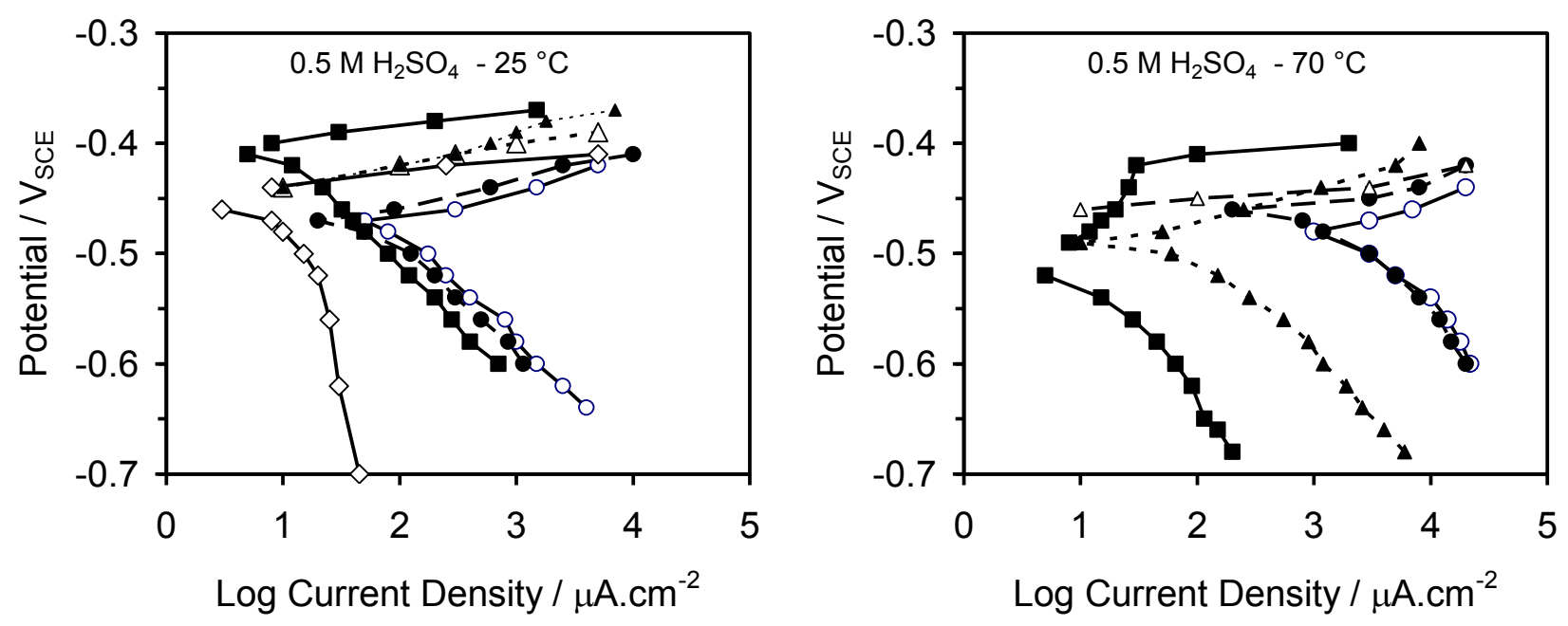

Figures 2. Polarization curves of Armco iron after $24 \mathrm{~h}$ immersion in $0.5 \mathrm{M} \mathrm{H}_{2} \mathrm{SO}_{4}$ solution at $25^{\circ} \mathrm{C}$ (left) and $70^{\circ} \mathrm{C}$ (right) in the presence of the $1-\mathrm{H}$ series derivatives at $1 \mathrm{mM}$ concentration: blank, open circles; 1-H, full circles; 1-Cl, open triangles; 1-Br, full triangles; 1-I, full squares, OCT, open diamonds.

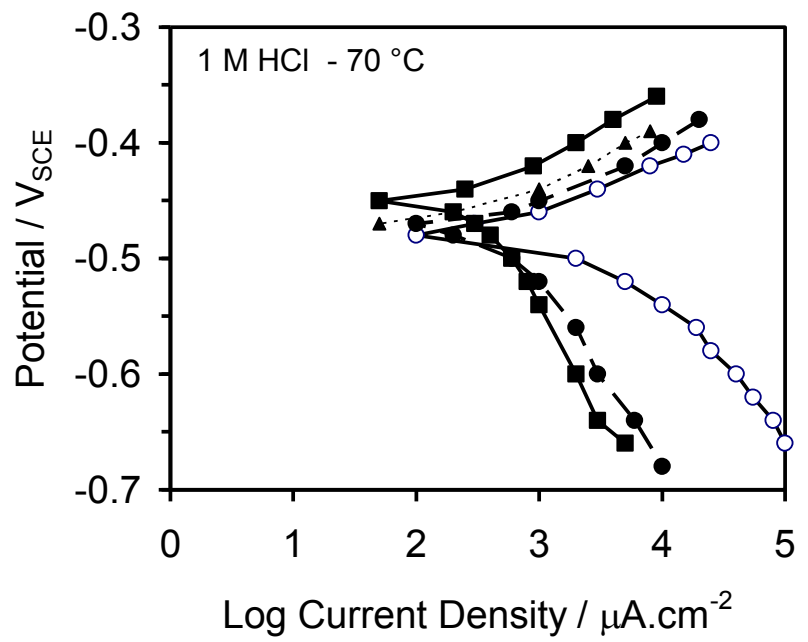

Figure 3. Polarization curves of Armco iron after $2 \mathrm{~h}$ immersion in $1 \mathrm{M} \mathrm{HCl}$ solution at $70^{\circ} \mathrm{C}$ in the presence of $1-\mathrm{H}$ series derivatives at $1 \mathrm{mM}$ concentration: blank, open circles; $1-\mathrm{H}$, full circles; 1-Br, full triangles; 1-I, full squares.

With alkynols, the lengthening of their aliphatic chain produced very interesting results and the longer this chain, the more significant the inhibiting action. In fact, OCT was the most efficient among the tested alkynols (Table 3). In these acid solutions, alkynols generally performed their action mainly by inhibiting the hydrogen evolution reaction (Figs. 4 and 5); for instance, in the sulphuric acid solution at $70^{\circ} \mathrm{C}$ (Fig. 4), BUT scarcely influenced the cathodic process, while HEX reduced the cathodic polarization currents to a certain extent, and OCT to a remarkable extent. Higher effects were determined in the hydrochloric acid solution (Fig. 5). Only the higher homologue (OCT) hindered markedly the anodic process, chiefly in the hydrochloric acid solution. 
Table 3. \%I.E. values for the various compounds from iron corrosion currents determined by cathodic Tafel line extrapolation to the corrosion potentials.

\begin{tabular}{|c|c|c|c|c|}
\hline \multicolumn{2}{|l|}{ ADDITIVE } & \multicolumn{2}{|c|}{$0.5 \mathrm{M} \mathrm{H}_{2} \mathrm{SO}_{4}$} & \multirow{2}{*}{$\begin{array}{c}1 \mathrm{M} \mathrm{HCl} \\
70^{\circ} \mathrm{C} \\
\end{array}$} \\
\hline & & $25^{\circ} \mathrm{C}$ & $7^{\circ}{ }^{\circ} \mathrm{C}$ & \\
\hline \multirow{4}{*}{$\begin{array}{l}\text { 3-Hydroxy-3M1B } \\
\left(\mathrm{CH}_{3}\right)_{2} \mathrm{C}(\mathrm{OH}) \mathrm{C} \equiv \mathrm{C}-\mathrm{X}\end{array}$} & $1-\mathrm{H}$ & 25 & 22 & 86.6 \\
\hline & $1-\mathrm{Cl}$ & 60 & 46 & 89 \\
\hline & $1-\mathrm{Br}$ & 63 & 67 & 86.6 \\
\hline & $1-\mathrm{I}$ & 90 & 99.7 & 89 \\
\hline \multirow{4}{*}{$\begin{array}{l}\text { 3-Hydroxy-ethoxy-3M1B } \\
\left(\mathrm{CH}_{3}\right)_{2} \mathrm{C}\left(\mathrm{OCH}_{2} \mathrm{CH}_{2} \mathrm{OH}\right) \mathrm{C} \equiv \mathrm{C}-\mathrm{X}\end{array}$} & $2-\mathrm{H}$ & - & 27 & 84.4 \\
\hline & $2-\mathrm{Cl}$ & - & 42 & 92.8 \\
\hline & $2-\mathrm{Br}$ & - & 82 & 94.2 \\
\hline & $2-\mathrm{I}$ & - & 99.8 & 95.8 \\
\hline 1-Butyn-3-ol & BUT & - & 62 & 87.5 \\
\hline $\mathrm{CH}_{3} \mathrm{CH}(\mathrm{OH}) \mathrm{C} \equiv \mathrm{C}-\mathrm{X}$ & BUT-I & - & 96.2 & 97.5 \\
\hline 1-Hexyn-3-ol & HEX & - & 96 & 95.6 \\
\hline $\mathrm{CH}_{3}\left(\mathrm{CH}_{2}\right)_{2} \mathrm{CH}(\mathrm{OH}) \mathrm{C} \equiv \mathrm{C}-\mathrm{X}$ & HEX-I & - & 99.3 & 99.6 \\
\hline 1-Octyn-3-ol & OCT & 95 & 99.7 & 99.4 \\
\hline $\mathrm{CH}_{3}\left(\mathrm{CH}_{2}\right)_{4} \mathrm{CH}(\mathrm{OH}) \mathrm{C} \equiv \mathrm{C}-\mathrm{X}$ & OCT-I & - & 99.95 & 99.97 \\
\hline
\end{tabular}
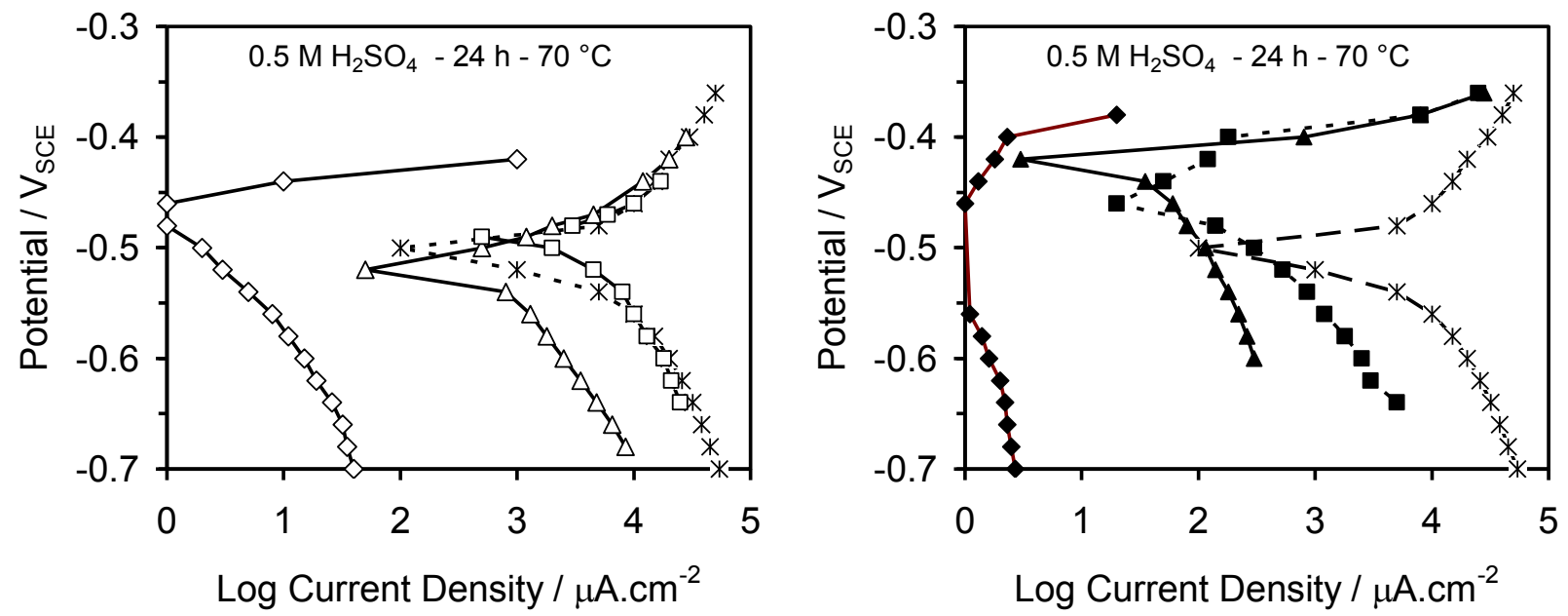

Figures 4. Polarisation curves of Armco iron after $24 \mathrm{~h}$ immersion in $0.5 \mathrm{M} \mathrm{H}_{2} \mathrm{SO}_{4}$ at $70^{\circ} \mathrm{C}$ (stars) and in the presence of $1 \mathrm{mM}$ BUT (open squares), BUT-I (full squares), HEX (open triangles), HEX-I (full triangles), OCT (open diamonds) and OCT-I (full diamonds). 

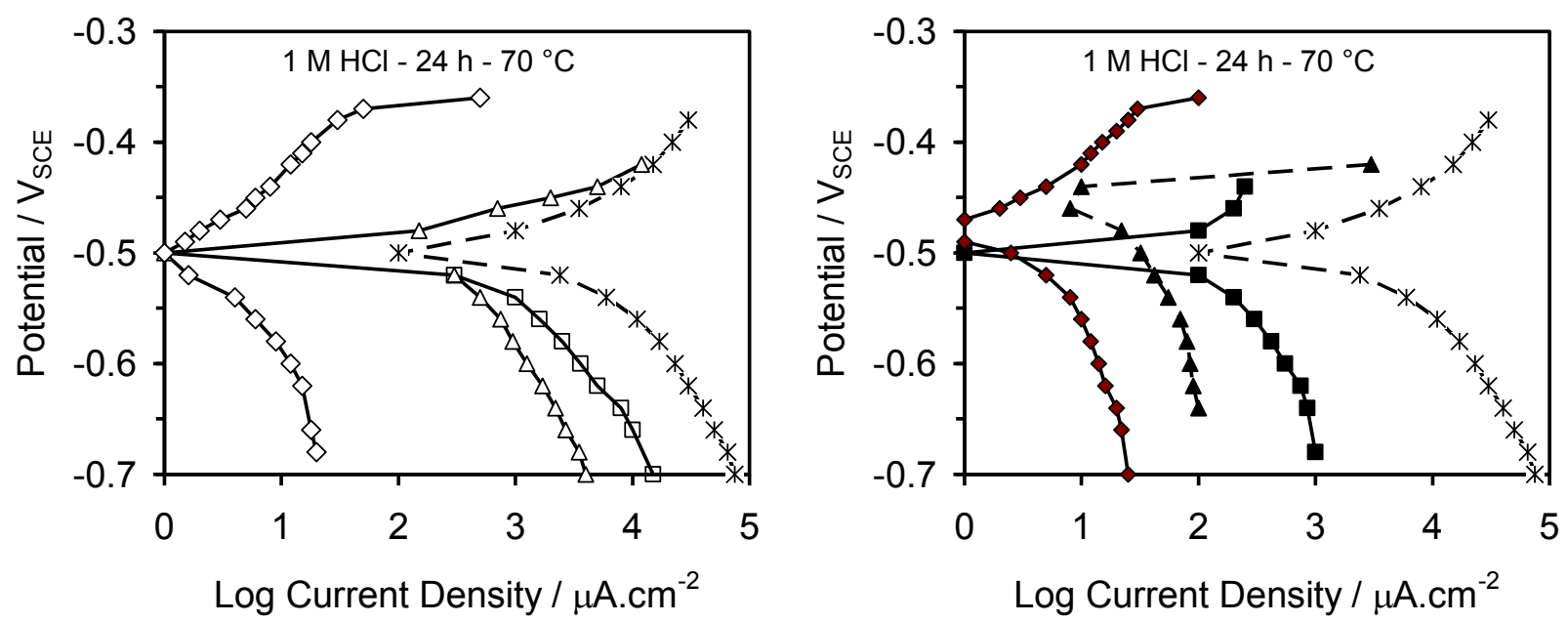

Figures 5. Polarisation curves of Armco iron after $24 \mathrm{~h}$ immersion in $1 \mathrm{M} \mathrm{HCl}$ at $70{ }^{\circ} \mathrm{C}$ (stars) and in the presence of $1 \mathrm{mM}$ BUT (open squares), BUT-I (full squares), HEX (open triangles), HEX-I (full triangles), OCT (open diamonds) and OCT-I (full diamonds).

The substitution of the acetylenic hydrogen atom with the iodine atom strengthened the inhibiting action of these alkynols by further reducing the cathodic currents. For instance, between an alkynol and its corresponding iodo-derivative, usually about one order of magnitude differences were found in the cathodic currents.

The anodic polarization currents too were decreased and with OCT-I a wide potential interval of anodic inhibition was determined in the sulphuric solution. However, in the hydrochloric acid solution, after $24 \mathrm{~h}$ immersion, OCT and OCT-I displayed almost equal inhibiting effects, so that limited differences were found in their polarization curves.

Table 3 collects \%I.E. values determined by the extrapolation of the cathodic polarization curves (Figures 2-5) to the corrosion potentials. These data match well with the corresponding \%I.E. values derived from dissolved iron analysis.

\section{3) Impedance spectra}

In general, impedance spectra (Nyquist plots) of the Armco iron in the presence of unsubstituted and substituted molecules of $3 \mathrm{M} 1 \mathrm{~B}$ derivatives were similar to the spectrum of Armco iron in the uninhibited acid solutions, i.e. a single, scarcely depressed, capacitive semicircle followed, at times, for frequencies lower than $1 \mathrm{~Hz}$, by a not well defined loop in the inductive quadrant. The size of the capacitive semicircle increased in relation to the sequence of increasing halo-atom polarizability (Fig. 6) and larger values were measured in hydrochloric acid solution than in the sulphuric one.

With most efficient alkyn-3-ols the shape of the capacitive semicircles turned into a depressed semicircle, with the possible appearance of a further low frequency capacitive loop; the higher their efficiency (i.e., the larger the semicircle), the more evident this behaviour. For instance, in the case of OCT in the hydrochloric acid solution at $70^{\circ} \mathrm{C}$, after few hours the impedance spectra started to develop a second capacitive loop, which was clearly evident after a prolonged immersion time (i.e., 24 h, Fig. 7 left). At times, the iodo- 
compounds of the 1-H and 2-H series were also characterized by a similar behaviour, but with the second low frequency time constant much less well defined (Fig. 7 right).

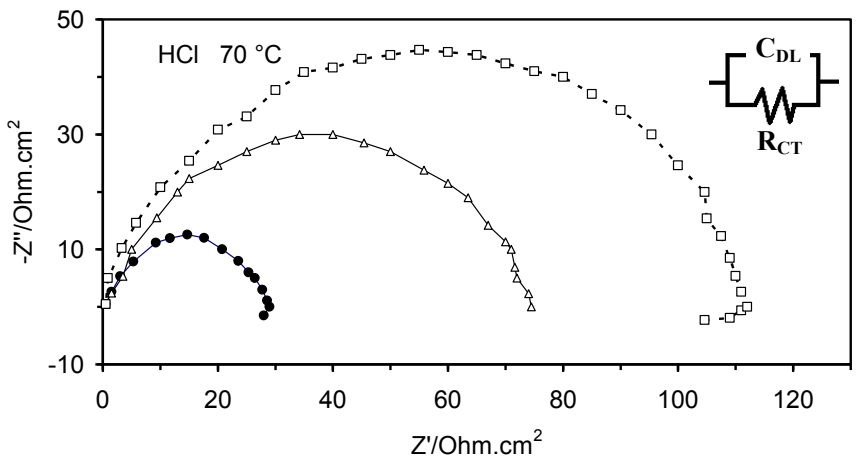

Figure 6. Impedance spectra of Armco iron in $1 \mathrm{M} \mathrm{HCl}$ at $70^{\circ} \mathrm{C}$, in the presence of $1 \mathrm{mM}: 2-\mathrm{H}$ (full circles), 2-Br (open triangles), 2-I (open squares), after $3 \mathrm{~h}$ immersion.
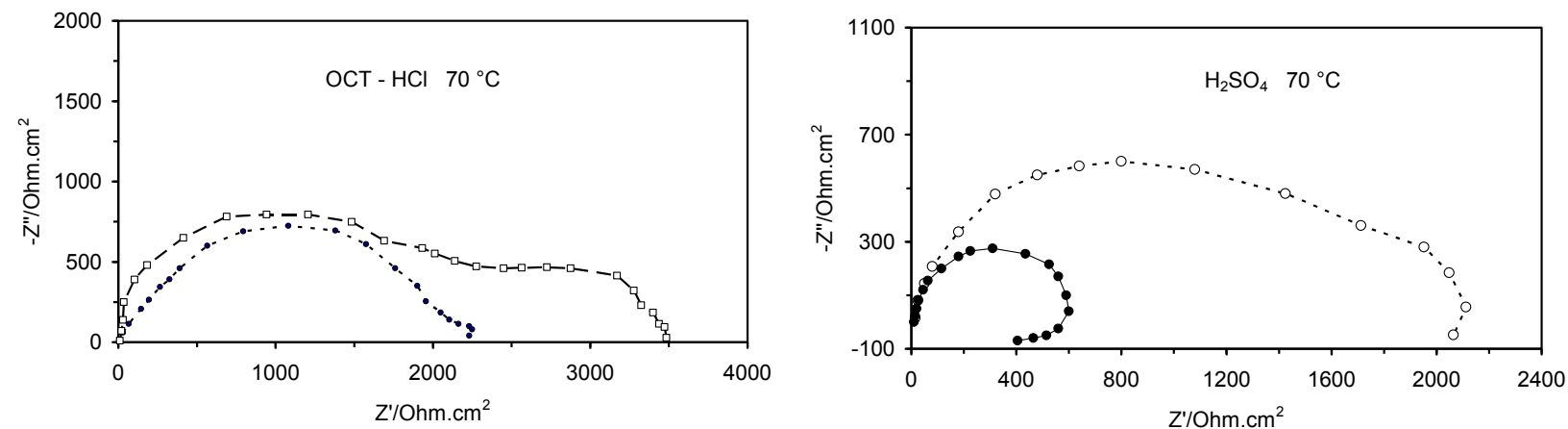

Figures 7. Impedance spectra of Armco iron in: left) $1 \mathrm{M} \mathrm{HCl}$ at $70^{\circ} \mathrm{C}$, in the presence of $1 \mathrm{mM}$ OCT after $30 \mathrm{~min}$ (full circles) or $24 \mathrm{~h}$ (open squares) immersion; right) $0.5 \mathrm{M} \mathrm{H}_{2} \mathrm{SO}_{4}$ at $70^{\circ} \mathrm{C}$, in the presence of $1 \mathrm{mM} \mathrm{1-I}$ after $6 \mathrm{~h}$ (full circles) or $24 \mathrm{~h}$ (open squares) immersion.

The experimental data of the impedance spectra recorded in the presence of $3 \mathrm{M} 1 \mathrm{~B}$ derivatives were satisfied by an Electrical Equivalent Circuit (EEC) simply formed by a network of a resistance ( $R_{\mathrm{CT}}$, the charge transfer resistance) in parallel to a capacitance $\left(C_{\mathrm{DL}}\right.$, the double layer capacitance), i.e., that the corrosion process was chiefly chargetransfer controlled, as it was in uninhibited acid solutions.

In the case of OCT, an EEC satisfying the experimental data had also to take into consideration a diffusion-related element, i.e. an arm formed by a resistance $(r)$ in series with a generalized finite Warburg element (W) in parallel to the previously-described network. The impedance expression of the generalized finite Warburg element (W) is:

$$
Z_{\mathrm{W}}=R_{\mathrm{W}} \operatorname{tgh}\left[(i T \omega)^{\mathrm{P}}\right] /(i T \omega)^{\mathrm{P}}
$$

where $\omega=2 \pi f\left(\mathrm{rad} \mathrm{s}^{-1}\right), i=(-1)^{1 / 2}$, and the parameters $R_{\mathrm{W}}\left(\Omega \cdot \mathrm{cm}^{2}\right), T\left(\mathrm{~s}^{-1}\right)$ and $P(0 \leq P \leq 1)$ are coefficients of the generalized finite Warburg element. $T$ corresponds to $L^{2} / D$, where $L$ is the effective diffusion layer thickness and $D$ is the effective diffusion coefficient of the species. 
For instance (Fig. 8), for OCT, the following parameters satisfied the impedance spectra recorded after $24 \mathrm{~h}$ immersion in $0.5 \mathrm{M} \mathrm{H}_{2} \mathrm{SO}_{4}$ solution: $R_{\mathrm{CT}}=2300 \Omega \cdot \mathrm{cm}^{2}, C_{\mathrm{DL}}=$ $1.6 \cdot 10^{-8} \mathrm{~F} \cdot \mathrm{cm}^{-2}, r=1198 \Omega \cdot \mathrm{cm}^{2}, R_{\mathrm{W}}=1.10^{5} \Omega \cdot \mathrm{s}^{-1}$ (rounded value), $T=200, P=0.5$.

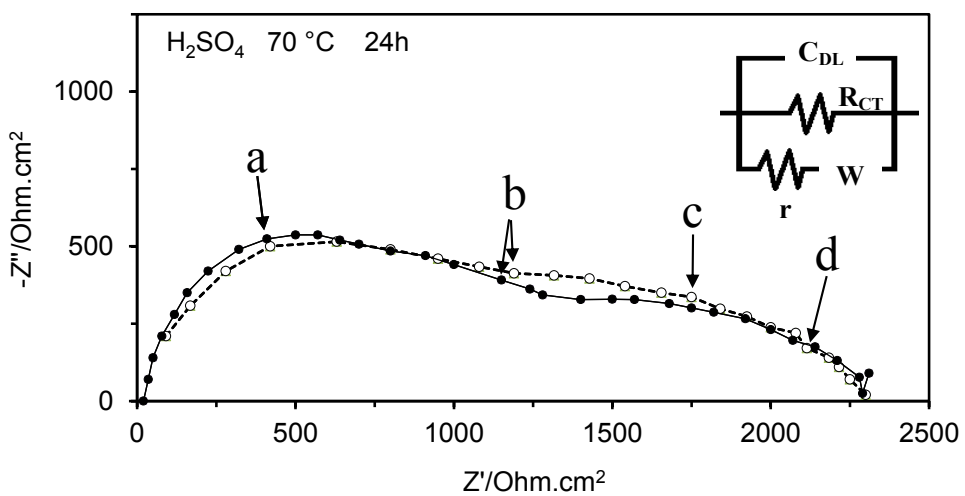

Figure 8. Impedance spectra of Armco iron after $24 \mathrm{~h}$ immersion in $0.5 \mathrm{M} \mathrm{H}_{2} \mathrm{SO}_{4}$ at $70^{\circ} \mathrm{C}$ inhibited by $1 \mathrm{mM} \mathrm{OCT} \mathrm{(full} \mathrm{circles)} \mathrm{and} \mathrm{simulated} \mathrm{values} \mathrm{(open} \mathrm{circles).} \mathrm{Frequencies:} a$, $10 \mathrm{kHz} ; b, 1 \mathrm{kHz} ; c, 0.1 \mathrm{kHz} ; d, 10 \mathrm{~Hz}$.

The inhibiting action of the alkynols improved (i.e. the value of $\mathrm{Rp}$ increased), and simultaneously the persistence of such action was prolonged by lengthening their aliphatic chain (Fig. 9) or by introducing the iodine atom. For instance, in the sulphuric solution, the maximum inhibiting action of BUT lasted few hours (4), that of HEX around $6 \mathrm{~h}$, whereas that of OCT for about 24 hours. With the introduction of the iodine atom BUT-I and HEXI prolonged their protective effects for longer than $24 \mathrm{~h}$.
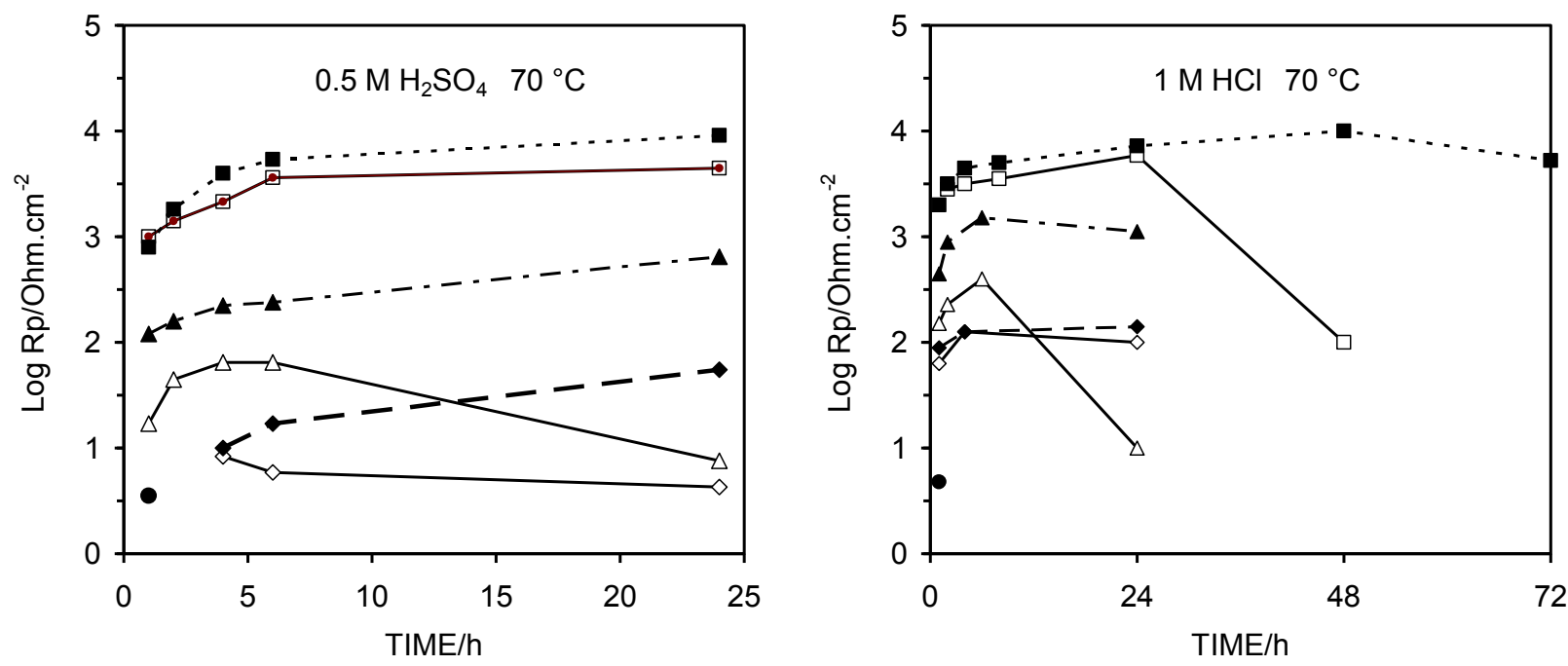

Figures 9. Trends of $\mathrm{Rp}$ as a function of time for the various alkynols ( $1 \mathrm{mM}$ concentration) in the sulphuric (left) or hydrochloric (right) acid solutions: BUT (open diamonds), BUT-I (full diamonds), HEX (open triangles), HEX-I (full triangles), OCT (open squares) and OCT-I (full squares), blank (full circles). 
While in the sulphuric acid solution the presence of the iodine atom determined an improvement in the inhibiting action, as far as both magnitude and time were concerned, in the hydrochloric acid solution it chiefly lengthened the persistence of the inhibiting effects, that lasted longer than $24 \mathrm{~h}$ for HEX-I, and $48 \mathrm{~h}$ for OCT-I (in comparison to $6 \mathrm{~h}$ for HEX and $24 \mathrm{~h}$ for OCT).

In general, the agreement between the corrosion rate values obtained from the extrapolation of the cathodic polarization curves to the corrosion potential with those derived from impedance spectra analysis can be considered to be satisfactory (Table 4).

Table 4. Comparison between the corrosion currents (in $\mu \mathrm{A} \cdot \mathrm{cm}^{-2}$ ) from polarization curves and impedance measurements ( $i_{\mathrm{CORR}}=B / \mathrm{Rp}, \mathrm{B}=20 \mathrm{mV}$ [24]) in $0.5 \mathrm{M} \mathrm{H}_{2} \mathrm{SO}_{4}$.

\begin{tabular}{|c|c|c|c|c|}
\hline \multirow[b]{2}{*}{ ADDITIVE } & \multicolumn{2}{|c|}{ Corrosion currents $/ \mu \mathrm{A} \cdot \mathrm{cm}^{-2}$} & \multirow[b]{2}{*}{$\mathrm{Rp} / \Omega \cdot \mathrm{cm}^{2}$} & \multirow[b]{2}{*}{$C_{\mathrm{DL}} / \mu \mathrm{F} \cdot \mathrm{cm}^{-2}$} \\
\hline & $\begin{array}{c}\text { Polarization } \\
\text { curves }\end{array}$ & EIS & & \\
\hline blank & 4000 & 4000 & 5 & 150 \\
\hline $1-\mathrm{H}$ & 780 & 700 & 30 & 59 \\
\hline $1-\mathrm{Cl}$ & 360 & 400 & 50 & 50 \\
\hline $1-\mathrm{Br}$ & 290 & 280 & 70 & 32 \\
\hline $1-\mathrm{I}$ & 210 & 170 & 120 & 36 \\
\hline $\mathrm{OCT}$ & 5 & 8.7 & 2300 & 0.016 \\
\hline
\end{tabular}

\section{Discussion}

It is well known that organic compounds with an acetylenic bond form, on the metal surface, a polymeric film which performs its inhibiting action chiefly by hindering the cathodic hydrogen evolution reaction [6,7,30-38], while the anodic process, too, is retarded only by very protective layers [27-29]. The formation of such a polymeric layer involves an initial stage of chemisorption through $\pi$ electrons of the triple bond and a final polymerisation/reticulation stage, sustained by a rise in the temperature.

The tests at low temperature show that in $3 \mathrm{M} 1 \mathrm{~B}$ derivatives the substitution of the acetylenic hydrogen atom with more and more easily polarizable halogen atoms, which should favour chemisorption, positively influences the inhibitive performances. It is mainly the anodic reaction that is involved in the improvement of inhibiting action, and this can be linked to a preferential adsorption of such derivatives on metal sites characterized by anodic behaviour, with a consequent enlarged surface coverage and a hindrance to the anodic process. When the temperature is raised, following a stimulated polymerization, the cathodic reaction also becomes markedly inhibited. From $C_{\mathrm{DL}}$ values (a few tens of $\mu \mathrm{F} \mathrm{cm} \mathrm{cm}^{-2}$ ) in impedance spectra, it is likely these derivatives build a thin (few $\AA$ thick) film, which exerts its action by a blocking effect of the active metal surface, as indicated by the 
cathodic Tafel slope which is almost equal to that of the uninhibited solution. In this case the corrosion process remains charge-transfer limited, as the blank.

An appropriate lengthening of the aliphatic tail $(R)$ in the alkynols leads to a noticeable improvement in their inhibiting action, as occurs in alkynes [39], nitriles [40], and mercaptans [41]. Such an improvement may depend on different causes: stronger Van der Waals interactions between the chains, increase in the thickness of the polymolecular layer [7] or increased hydrophobic characteristics of the film [42, 43]. Yang [20] emphasised that the longer the alkynol saturated hydrocarbon chain, the faster the polymer film growth rate, and the higher the maximum surface coverage. In this regard, it has been observed that the resulting metal corrosion rate is related to the thickness of the polymeric organic layer and that films thicker than around $100 \AA$ are characterised by very high protective effects [8].

In the present case, for $\mathrm{OCT}$, the $\mathrm{C}_{\mathrm{DL}}$ values from impedance spectra shift from an initial value of some $\mu \mathrm{F} \mathrm{cm}^{-2}$ to a final value of a few hundredths of $\mu \mathrm{F} \mathrm{cm}$, pointing to a transition from a few $\AA$ thick layer to one a few thousands $\AA$ thick. The corrosion process, over time, shows a transition from an initial charge-transfer limited corrosion mechanism (like $3 \mathrm{M} 1 \mathrm{~B}$ derivatives) to a diffusion-limited process. It is likely that the initially formed thin film performs its action by a blocking surface mechanism, while the successively developed thick film acts as a strong physical barrier to $\mathrm{H}^{+}$discharge, as evidenced both by the strikingly reduced cathodic polarization currents and the marked increase in the cathodic Tafel slope. This protective layer also performs a noticeable retarding action for iron anodic dissolution, at least up to a certain potential, where inhibitor desorption can take place.

According to Hausler [2], the phase formed by 3M1B derivatives should consist of an inhibitor-chelate layer (protective complex) and with this type of film the corrosion process is under charge-transfer control. In the thicker layer formed by OCT, hydrodynamicboundary layer conditions should predominate, and in this case the corrosion process becomes diffusion limited. These diffusion limitation effects may also begin to take place in the case of the most efficient 3M1B compounds (i.e., the iodo-derivatives).

In alkynols (like in 3M1B derivatives), the substitution of the acetylenic hydrogen atom with the iodine atom causes a considerable improvement in the inhibiting action and, at the same time, an extension in its persistence. It can be supposed that the easily polarizable halogen atom favours and strengthens the chemisorption of the acetylenic compounds onto the iron surface and this sustains the formation of a more effective and persistent film.

\section{Conclusions}

1. The substitution of the acetylenic hydrogen atom with halo-atoms improves the inhibiting action to the anodic reaction, the higher the polarizability, the greater the effect. It can be supposed that the easily polarizable halogen atom favours and strengthens the chemisorption of the acetylenics onto the iron surface, which supports the formation of a more complete inhibitor layer. 
2. The presence of a long aliphatic chain, allowing the building of a thicker layer, increases the inhibiting effects not only towards the cathodic hydrogen evolution reaction, but also, for the most efficient compounds, towards the anodic iron oxidation process. The longer the alkyl tail, the more evident these effects.

3. The iodine atom improves the protective characteristics and persistence of the alkynols, also in the case of alkynols which possess, per se, a noticeable efficiency (i.e., OCT).

4. While for the less efficient acetylenics the corrosion process is under charge-transfer limitations, with the most efficient ones it becomes diffusion limited.

\section{References}

1. G. Schmitt, Br. Corros. J., 1984, 19, 165.

2. R. H. Hausler, Corrosion Chemistry, G.R. Brubaker et al. Eds., 89 ACS Symp. Series, 1979, Washington, DC, Chapter 9.

3. N. I. Podobaev and Ya. G. Avdeev, Prot. Met., 2002, 38, 51.

4. N. I. Podobaev and Ya. G. Avdeev, Prot. Met., 2004, 40, 7.

5. Ya. G. Avdeev and Yu. I. Kuznetsov, Russ. Chem. Rev., 2012, 81, no. 12, 1133.

6. I. N. Poutilova, Proc. European Symp. on Corros. Inhibitors, (Ferrara, Italy, 28 Septembre - 1er Octobre 1960), Ann. Univ. Ferrara, NS., Sez.V, Suppl. n. 3, 1960, p. 139.

7. S. B. Balezin, N. I. Podobayev, A. G. Voskresensky and V. V. Vasiliyev, Proc. $3^{\text {rd }}$ Int. Congr. Metall. Corros. (Moscow 1963), Vol. 2, p. 9, Moscow, "Mir" Publishing house, 1969.

8. G. W. Poling, J. Electrochem. Soc., 1967, 114, 1209.

9. E. J. Duwell, J. W. Todd and H. C. Butzke, Corros. Sci., 1964, 4, 435.

10. F. B. Growcock, W. W. Frenier and V. R. Lopp, Proc. $6^{\text {th }}$ European Symp. on Corros. Inhibitors (Ferrara, Italy, $16^{\text {th }}-20^{\text {th }}$ September 1985), Ann. Univ. Ferrara, NS., Sez. V, Suppl. n. 8, 1985, Vol. 1, p .167 and p. 183.

11. G. Lendvay-Gyorik, G. Meszaros, B. Lengyel and G. Lendvay, Corros. Sci., 2003, 45, 1685.

12. C. Fiaud, A. Harch, D. Mallouh and M. Tzinmann, Corros. Sci., 1993, 35, 1437.

13. F. B. Growcock and R. V. Lopp, Corros. Sci., 1988, 28, 397.

14. M. E. Roselli, M. A. Sànchez, E. M. Macchi and J. J. Podestà, Corros. Sci., 1990, 30, 159.

15. P. Kutej, J. Vosta, J. Pancir and N. Hackerman, J. Electrochem. Soc., 1995, 142, 1847.

16. K. Aramaki and E. Fujioka, Corrosion, 1997, 53, 319.

17. V. Jovancicevic, Yang Bo and J. O’M. Bockris, J. Electrochem. Soc., 1988, 135, 94.

18. J. O'M. Bockris and Yang Bo, J. Electrochem. Soc., 1991, 138, 2237.

19. J. O'M. Bockris and Yang Bo, Electrochim. Acta, 1991, 36, 1333.

20. Yang Bo, N. G. Smart and J. O’M Bockris, Electrochim. Acta, 1992, 37, 317.

21. R. J. Tedeschi, Corrosion, 1975, 31, 130. 
22. N. I. Podobaev, V. E. Novikov and A. G. Voskresenskii, Zh. Prikl. Khim., 1974, 47, 370 (in Russian).

23. A. Frignani, C. Monticelli, M. Tassinari and G. Trabanelli, J. Appl. Electrochem., 1995, 25, 371.

24. A. Frignani, C. Monticelli and G. Trabanelli, Proc. $8^{\text {th }}$ European Symp. on Corros. Inhibitors (Ferrara, Italy, $18^{\text {th }}-22^{\text {nd }}$ September 1995), Ann. Univ. Ferrara, NS., Sez. V, suppl. n. 10, 1995, Vol. 1, p. 187.

25. A. Frignani, C. Monticelli and G. Trabanelli, Proc. $9^{\text {th }}$ European Symp. on Corros. Inhibitors (Ferrara, Italy, $4^{\text {th }}-8^{\text {th }}$ September 2000), Ann. Univ. Ferrara, NS., Sez. V, suppl. n. 11, 2000, Vol. 2, p. 749.

26. S. Seki, K. Nishihata and H. Ogawa, Chem. Abstr., 1966, 65, 16899a.

27. Ya. G. Avdeev and Yu. I. Kuznetsov, Korroz.: Mater. Zashch., 2009, no. 12, 4 (in Russian).

28. Ya. G. Avdeev, Yu. I. Kuznetsov and V. M. Larionova, Korroz.: Mater. Zashch., 2010, no. 10, 31 (in Russian).

29. Ya. G. Avdeev, Yu. I. Kuznetsov and A. K. Buryak, Corros. Sci., 2013, 69, 50.

30. E. J. Duwell, J. Electrochem. Soc., 1962, 109, 1013.

31. I. Epelboin, M. Keddam and H. Takenouti, Proc. $3^{\text {rd }}$ European Symp. on Corros. Inhibitors (Ferrara, Italy, $14^{\text {th }}-17^{\text {th }}$ September 1970), Ann. Univ. Ferrara, NS., Sez. V, suppl. n. 5, 1970, p. 237.

32. I. Epelboin, M. Keddam and H. Takenouti, J. Appl. Electrochem., 1972, 2, 71.

33. W. J. Lorenz and F. Mansfeld, Corros. Sci., 1981, 21, 647.

34. F. B. Growcock and R. J. Jasinski, J. Electrochem. Soc., 1989, 136, 2310.

35. T. Kristòf and T. Salamon, Werkst. Korros., 1990, 41, 519.

36. A. Rauscher, G. Kutsàn, Z. Lukàcs and E. Kàlmàn, Proc. $7^{\text {th }}$ European Symp. on Corros. Inhibitors (Ferrara, Italy, $17^{\text {th }}-21^{\text {st }}$ September 1990), Ann. Univ. Ferrara, NS., Sez. V, suppl. n. 9, 1990, Vol. 1, p. 293.

37. I. Hashi, Omar and F. Zucchi, ibidem, p. 321.

38. D. D. N. Singh and A. K. Dey, Corrosion, 1993, 49, 594.

39. F. Zucchi, G. L. Zucchini and G. Trabanelli, Proc. $3^{\text {rd }}$ European Symp. on Corros. Inhibitors (Ferrara, Italy, $14^{\text {th }}-17^{\text {th }}$ September 1970), Ann. Univ. Ferrara, NS., Sez.V, suppl.n.5, 1970, p.121.

40. V. Carassiti, F. Zucchi and G. Trabanelli, ibidem, p. 525.

41. G. Trabanelli, F. Zucchi, G. Gullini and V. Carassiti, Werkst. Korros., 1969, 20, 1012.

42. H. R. Baker, E. G. Shafrin and W. A. Zisman, J. Chem. Phys., 1952, 56, 404.

43. W.S. Dean, H. J. Deitzer and C. A. Cooper, CORROSION/79, Atlanta, 12-16 March 1979, paper n. 68 . 